\title{
IMPORTANT "PLACES" ON THE MAP OF KRAKOW - PUBLIC SPACES OF NOWA HUTA
}

\author{
Monika Borgiasz-Stepaniuk
}

\begin{abstract}
During the times of the Polish People's Republic, spaces, especially public ones, were marginalized. Concrete areas were used to cover up areas dedicated for people, thus limiting the ground reserved for a public space. Nowadays, public spaces are open, separated and identical with people. Important places for the local community are significant for the city's identity. That is where inhabitants live and meet each other. Public spaces perform different functions and should be for people and with people. The article presents the concept of public space in the city and shows examples of important places in the area of the youngest district of Cracow - Nowa Huta. Cracow, as a city with a collection of historical places, where the identity was created in the distant past, has a district where uniformity and a sense of social belonging rebuilds. There characteristic places take on a new look, whereas people give them a modern look, and therefore become social spaces. Places such as: the Nowohucki Lagoon, the Wanda Mound or the Central Square currently operate as public spaces that have undergone numerous sociocultural changes. They have become places of real interpersonal contacts.
\end{abstract}

Keywords: city, public space, places, Krakow

\section{Introduction}

Public space is nowadays an important element of the city's landscape. It combines its fragments, creating a frame for buildings and interpersonal relations. The public space is located in the city space. It is such a segment that is dedicated to residents and other subjects of social life. This space is available to the entire urban community, without the need for supplementary requirements. Public spaces in the city are characterized by openness, reachability and universality. They are the opposite of ownership spaces, which are usually discrete and private (Bartoszek, Gruszczyński, Szczepański, 1997, Liszewski, 2001, Franta, 2004, Hładkiewicz, 2006, Lorens, 2007, Kowalczyk, 2009, Cegłowska, Matykowski, 2010, Bierwiaczonek, Nawrocki, 2012).

Nowadays, the level of living and the value of the city is proven by, among other things, the harmoniousness, practicality and universality of public spaces. It is also one of the key factors of the city's social and economic development. Properly modeled public space affects the city's rank, and additionally improves the standard of living of residents. In this way, so-called megaproduct of the city 
whose attributes are uniformity and character. When assessing the city, its inhabitants and people who arrived there using the public space, they value and systematize it. Its elements make up the city's foundation (Bartoszek and others, 1997, Markowski, 2007, Dębińska, Kołsut, 2011).

The main public spaces of the city are, among others: streets, squares, parks, green areas, objects forming public goods (eg offices and public facilities) and landscape elements that are common property.

The aim of the study is to indicate public spaces and important places in the youngest district of Krakow - Nowa Huta. This district is located in the northeastern part of the city and is the largest in terms of area part of Krakow (65.41 $\mathrm{km}^{2}$ ). On the basis of direct observations, several areas were selected in Nowa Huta, which constitute the public space of this district.

The publication formulates two main cognitive questions:

- have the old public spaces been transformed nowadays?

- have new public spaces appeared in Nowa Huta?

In the reflections on public spaces, it is worth paying attention to the concept of "public". It is a term referring to something common, accessible and available. Thus, public space is open socially and important for the whole society.

\section{Public space of the city - significant space}

Public space is a unique type of urban space in which many types of space can be distinguished. In it, all changes are reflected in a specific reality. The word "public" includes places that are the property of the entire city community. It occurs as a material space, ie one that has the size, location and attributes that give it its peculiarity and uniqueness. Functions that a public space has in common with its construction, organization and use. Even such a space, which has imaginary grounds, plays a role equivalent to traditional spaces (Jałowiecki, Szczepański, 2009).

Cities have always had a characteristic form and appearance. Being a specific place, they had a specific meaning for a given community. In public spaces various social influences appeared, which influenced the rotation of information, customs and cultural values.

Space organization is important in creating specific attitudes among people. Social transformations in a given environment may depend on the layout of the space and its use. Such common levels cause events that will build common interpersonal relationships. Various activities and dialogue open space and facilitate contact.

In addition, taking into account social needs, you can create places in the public space that will give them a specific shape. Also important are spatial elements that man creates himself as his own contribution. It is then an empirical 
space. Public space is important in social consolidation. Through spatial organization, special places are created for the exchange of ideas and meetings. Important events and customs occurring in the public space are identified with it. In this way, an arena for the course of city life is organized. The implementation of specific social activities gives the opportunity to present a variety of feelings and feelings as well as hopes and desires. Places also give the prospect of a common expression of lifestyle.

An important perception of public space is showing its significance for specific social groups. They are residents, but also other recipients. Space in space is used by both adults and children. These are areas of meetings and games and are organized in this way (Riggo, 2002).

The layout of the space in the city should serve its residents. It is the people living in a given place that should be the primary recipients of all socio-economic and spatial changes in the city. Institutions dealing with the organization of the environment must take into account social development and security as necessary activities in the creation of space. The availability of places, their infrastructure and development opportunities shape the proper and properly organized social environment (Kotkin, 2007).

A man shaping a given space perceives it individually and subjectively. He skillfully distinguishes those elements that will and will not serve him. Thus, he develops clear and transparent spaces that will confirm his identity. A developed society will create conditions in which the word "we" covers everyone who lives nearby. The rules and canons of mutual relations will concern the greater part of the community. In contemporary cities, public spaces are shaped by reference to the principles of the community that is utilizing (having) a given area. In this way, peculiar features are noticed, noticeable by external groups and addressed to them (Karwińska, 2008).

Today's cities and their public spaces most often express specific communities. A separate culture, social needs and aspirations create independent and separate information recorded in space. Individuals and social groups can nowadays participate in arranging and using the space in a typical way. The consequence of such activity is the creation of intensified public spaces, sometimes filled up with a social dimension. In such situations, incompatibilities and mutual reluctance may occur.

In conclusion, the public space has two dimensions. The first is the material approach, and the second is the social aspect. In the first perspective, the space is available to everyone who wants to use it. Real and original, it has to respond to public expectations and preferences. It should concentrate people and be for them to grasp (eg with the eyes). Strengthening social activities in the city, it is a friendly and valuable space. The social dimension of public space are places for those who use it. Seen and separated by data of a community, it becomes defined and marked. It is important that it be approved, secure and secured. Cannot 
produce a sense of separateness and discouragement. It is supposed to give a sense of real and mental safety. Defined as a "friendly" space, that is favorable and kind (Frysztacki, 2005).

\section{Public space of Nowa Huta - important places}

The compatibility of public spaces in the historical past has been disturbed many times. It encountered elimination, difficulties and obstacles, minimizing the possibility of completing the city's concept. For example, in cities covered by autocratic power, public spaces were to act for the state as a place for verification of social behaviors, unaccepted by superiors. Often, public spaces developed without understanding them and without any chance to secure them.

Today, many public places bear in themselves the past and evidence of the behavior of previous societies. They show discrepancies and social splits, but also cooperation. Social habits and social configurations, presenting specific approaches to life, form social and spatial configurations. Urban communities are consolidating around them, cultivating specific values. It is a long-term process, but in the end it is systematized and standardized universally.

This enables a particular community to spot spatial knowledge and find a place. Safe and safe location that gives you the opportunity to preserve social periphery. However, it is not always possible. Public spaces of the city can constitute a common and civilization "deserts" in which there are no symbols or features important for a given community (Billert, 2012).

The public spaces in many cities suggests that communities do not quite have the sense of importance and significance of these places for urban resources. Residents do not always want to participate in decorating spaces, especially those that have a modern character. New public spaces, but also those already existing, should have clearly defined principles of formation and use, and a fairly established responsibility for their appearance and protection as well as transformation and commercialization.

Socialist times were a thing of the past that hampered the processes of cohesive socio-economic development. Nowadays, in some spaces you can see the remains of left-wing elements on which the links of the present overlap. Such a spatial mosaic accumulates social and moral components, constituting different systems. Such circumstances intensify discrepancies and comparisons, but also bring about turmoil and social disorder in the life of the city. These remnants of the times of the People's Republic of Poland include, among others: buildings, monuments, decorations and "socialist" accents. Some of them can be easily changed, others are preserved, despite the association. Remnants from the past concern not only material elements, but also social life. In many cities, socio-economic and spatial changes were delayed due to past accretions. Nowa Huta was the area - the youngest district in Krakow. For a long time, perceived 
negatively by its image. The confirmation of this state of affairs is research carried out at the beginning of the 1990 s by H. Libura. The results of these studies clearly indicated that the inhabitants of Krakow were skeptical about this district, placing it as a "bad place". In addition, Nowa Huta was assessed as "foreign", ie with the immigrant population (Libura,1990).

The contemporary public spaces of Nowa Huta, unkindly evaluated in the past, have recently played an important role in shaping the character of Krakow. Getting to know places and decrypting them gives them meaning and dimension. We identify them as users, creating images and images that show their peculiarities. We often look for the "soul" of the place, showing its activity (de Certeau, 1984, Hansen, Verkaaik, 2009). Nowa Huta becomes an area with a "soul" that creates its image differently from other districts of Kraków. Nowa Huta District tries to charm with the distinctiveness and uniqueness of places that build her identity. Elements associated with the PRL times have become parts of the cultural heritage of this area.

It should be noted here that the history of Nowa Huta dates back to much earlier times than socialist times. Tradition and culture in these regions dates back to the Middle Ages, where there were several villages in this area, with the seats of the families, among others Branickich and Odrowąż. In 1947, after making the decision to build a plant, the peasants from the area of the present Nowa Huta began to be expropriated (Gryczyński, 2007).

The public space of this district began to change in the early 1990s. As a socialist city, Nowa Huta was almost entirely dependent on industry and its development. Kombinat was the most important factor in the city's growth, not only as a workplace, but also as an access to a variety of goods and services. It concentrated society and shaped social bonds. As a result of political and economic changes at the end of the 20th century, the landscape of Nowa Huta began to change slowly. Overcoming existing models of functioning of this district turned out to be very difficult. Not only because of the older part of the population, but also for the unrivaled buildings. However, the young generation began to change not only the city's public spaces, but also the way they were used. A number of organizations and associations were established in Nowa Huta, which ought to change the rank of this place among the districts of Krakow. The promotion of various initiatives and projects served to uncover the cultural and landscape values of this area (Gądek, 2006).

Below are examples of public spaces in Nowa Huta that affect the new image of this district of Cracow. The author of the publication compared selected examples of public spaces in the past and today. On this basis, a new image of the place was created. Unfortunately, it was an unwanted heritage of the PRL times.

Wanda's mound, erected in the 7th century and dedicated to Wanda, daughter of Krak, who did not want to marry a German (Figure 1). The mound is 14 meters high and about 50 meters wide at the base. At the top is a white eagle 
monument designed by Jan Matejko. Initially, at the top of the mound there was a wooden cross, which was liquidated in the 19th century.

Figure 1: Wanda's Mound

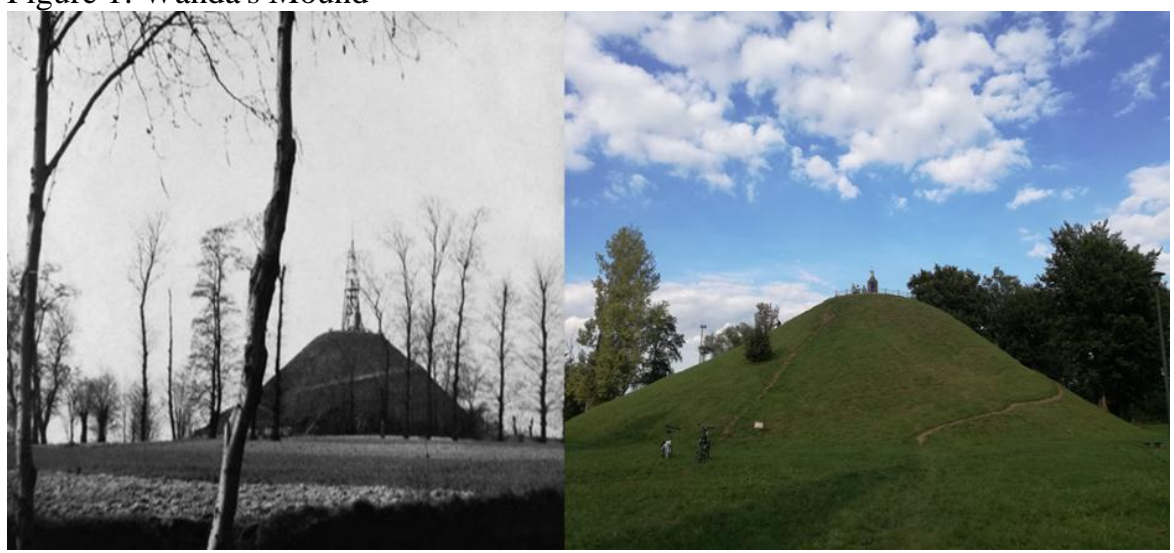

Source: https://podroze.onet.pl/polska, author

The lagoon of Nowa Huta was created in the 1950s and was a recreation area in the working-class district (Figure 2). It is an artificial reservoir and covers over 7 ha. Around the reservoir there was also a park, which was a walking place for the residents of Nowa Huta. Once forgotten and deserted, it is currently experiencing its renaissance. The lagoon was purified and the alleys around it were renovated. There are playgrounds, sports fields, an outdoor gym and a beach. In the middle of the reservoir is an island, which is now a breeding place for birds.

Figure 2: Lagoon Nowa Huta

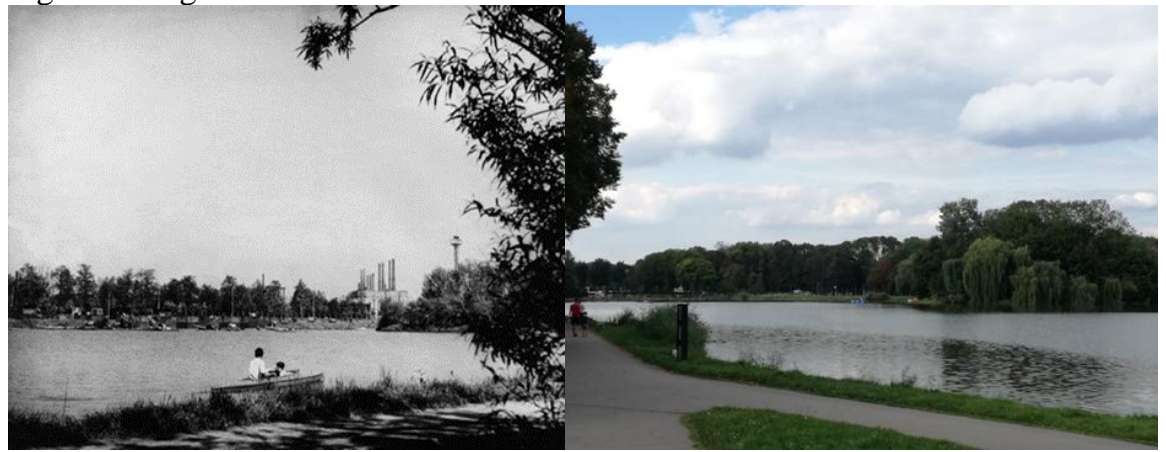

Source: https://podroze.onet.pl/polska, author 
Two buildings in the style of socialist realism are the administrative center of the Kombinat (Figure 3). The buildings are facing each other, connected by an underground passage. They are the image of the former Nowa Huta. They were built in 1952-1955 and designed by J. Ballenstedt and J. Ingarden. Moreover, the buildings are popularly called "The Vatican", because they refer to the Italian palaces of the Renaissance and Baroque style.

Figure 3: Metallurgical combine

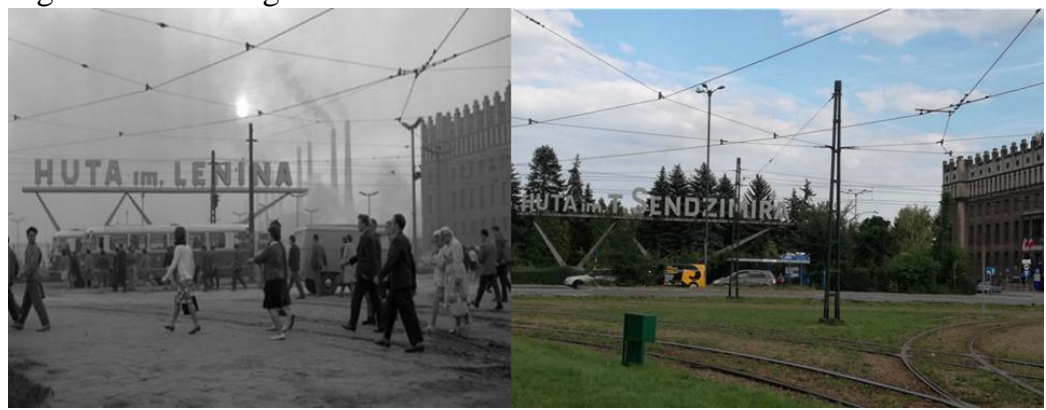

Source: https://podroze.onet.pl/polska, author

The next four photos show the Central Square, which was designed by T. Ptaszycki, and M. and J. Ingarden (Figure 4, 5, 6, 7). Its construction began in 1949. Its architecture refers to the Renaissance. It is symmetrically laid out and nowadays itis an important communication system between Nowa Huta and other districts of Cracow. Currently, it is named after Ronald Regan. From 1973 to 1989 on the Avenue of Roses, which is the main street of Nowa Huta, stood a statue of Lenin. Mass events are currently taking place here.

Figure 4: Central square

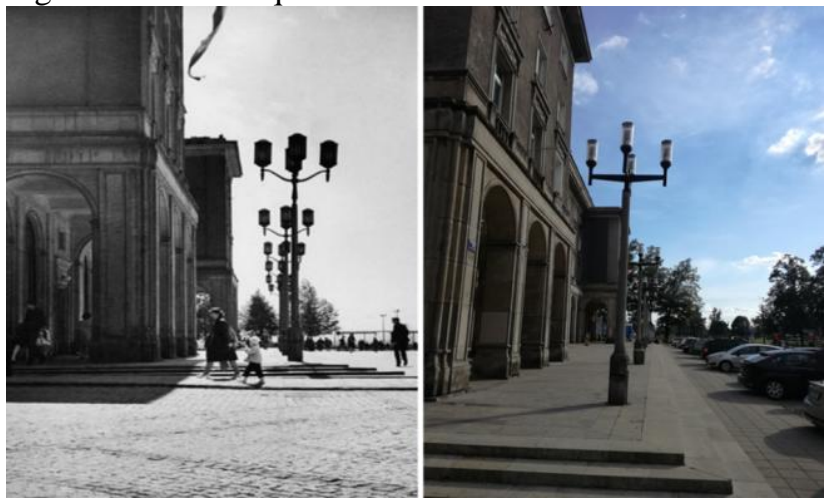

Source: https://podroze.onet.pl/polska, author 
Figure 5: Central square

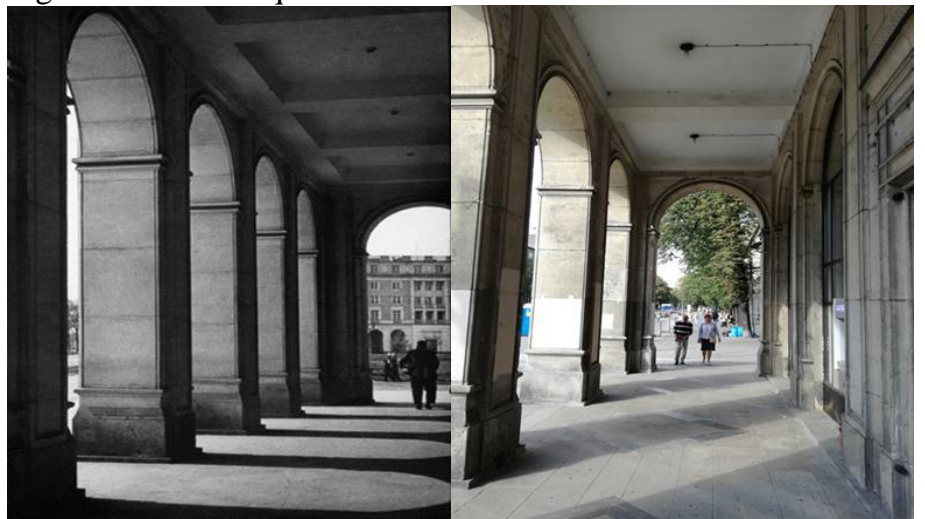

Source: https://podroze.onet.pl/polska, author

Figure 6: Central square

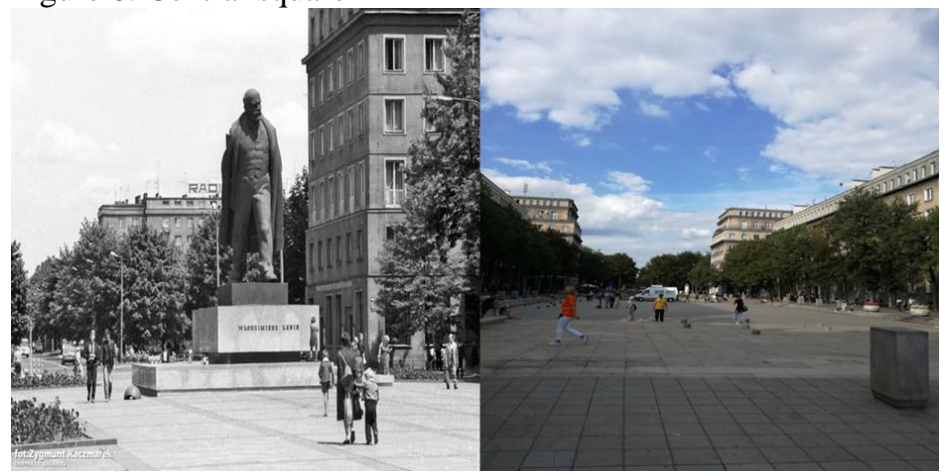

Source: https://podroze.onet.pl/polska, author

Figure 7: Central square

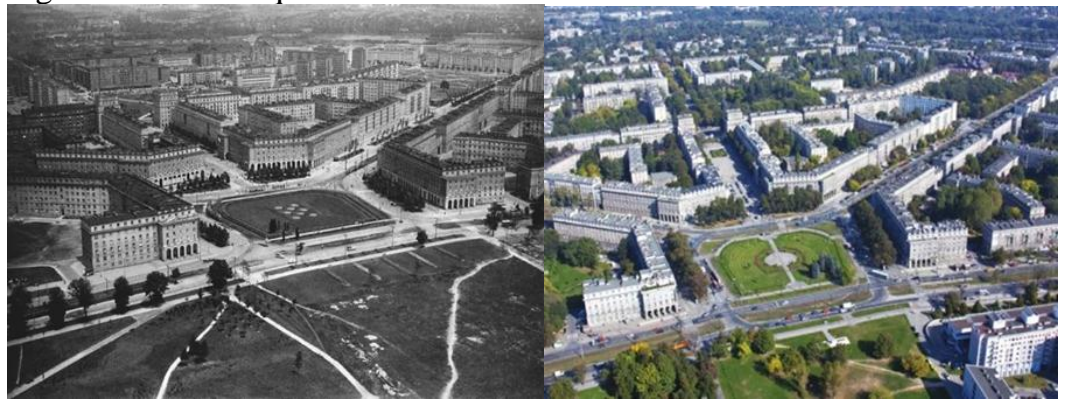

Source: https://podroze.onet.pl/polska 
The most popular cinema of Nowa Huta - "Świt" cinema began its activity in 1953 (Figure 8). The first film was "Three Stories" - novels about the construction of Nowa Huta. The cinema building is a socialist realism building with twelve columns and coping finials in front. The cinema was closed in 2002, later it was transformed into a shopping center.

Figure 8: Cinema "Świt"

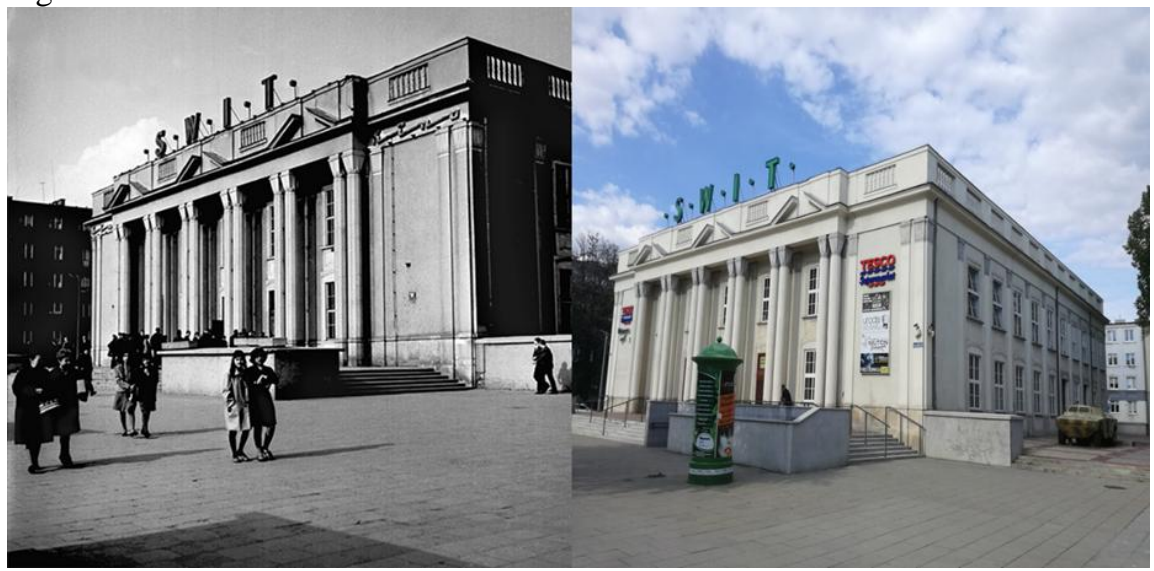

Source: https://podroze.onet.pl/polska, author

Figure 9: People's Theater

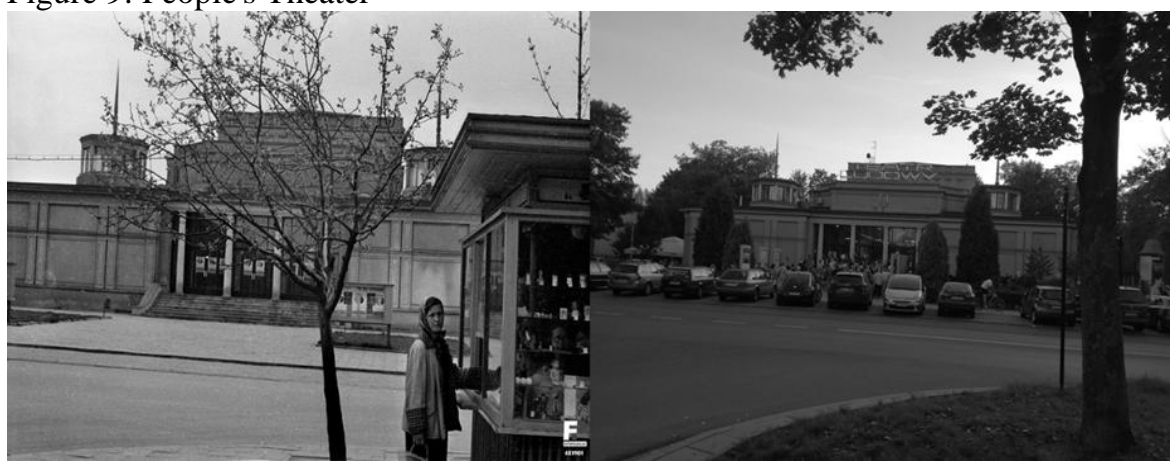

Source: https://podroze.onet.pl/polska, author

The People's Theater began its activity in 1955 (Figure 9). The first performance performed on the stage was "Krakowiacy i Górale" by Bogusławski. Many pre-premieres have been prepared here, not only national ones, but also world-wide. The Teatr Ludowy has been enjoying its splendor since 1989, when Jerzy Fedorowicz becomes the director. The first art exhibited in the theater at the 
time was "Man of marble - the beginning and the end". The new director creates the theater from scratch. The local community, but also other residents of Krakow, begin to visit the theater. Today, it is a place that has regained its local, as well as international position.

\section{Conclusion}

Public spaces are the subject of many scientific fields. These include: geography, urban planning, economics, and sociology. However, each of them looks at its characters in a different way (Słodczyk, 2001, Maik, 2011).

In the scientific literature, we will meet many expressions that concern public space. They usually indicate social interactions, i.e. these spaces, are treated as public areas. Available, separated, secure and having identity. The appropriate public space should satisfy all residents and attract people from the outside. Creating a community, culture and image, it builds a settlement unit with a specific identity (Kochanowska, 2009).

Public spaces should be places to integrate and realize the most important needs of society. Their appearance and character should reflect the spatial arrangement and order of the city.

Contemporary public spaces, including the spaces of Nowa Huta, undergo changes that are related to changes in many areas of life. They are real elements of every city. In the youngest district of Krakow, public spaces depart from the functional pattern established in the past and transform into places cultural where people can experience art and culture. Furthermore the social space is the place where the real social contacts with people are mode.

The transformation of the public spaces of Nowa Huta has been a long-term process, which is maintained so far. It required the involvement of many institutions and private individuals. It is worth remembering that interesting, transparent and open public spaces are the main stimulus affecting the choice of place to live.

\section{References}

BARTOSZEK, A. - GRUSZCZYŃSKI, L. A. - SZCZEPAŃSKI, M. S. 1997. A city and an apartment in social awareness. Katowice, 1997. ISBN 978-83-2261699-4.

BIERWIACZONEK, K. - NAWROCKI T. 2012. Theoretical look at public space. In Markets, malleas and cemeteries. Public space of Silesian cities in sociological terms. Cracow: Wydawnictwo Nomos, 2012. ISSN 0208-600X. pp. 23-64.

BILLERT, A. 2012. Culture and social and spatial development of cities. German experiences. In Culture-Policy-Development. About culture as a lever of social 
development of Polish metropolises and regions, Freedom and Solidarity, Kultura 44. 2012. Warsaw: Institute for Research on Market Economy, 2012. ISBN 978-83-7615-084-0, p. 20. [cit. 2018-09-15]. Available on the internet: http://www.malopolskie.pl/Pliki/2012/fokus_KOM.pdf.

CEGŁOWSKA, A. - MATYKOWSKI, R. 2010. Public spaces and their importance in a large city: the case of Poznań In Functions of cities as a factor shaping urban space, Urban Studies, No. 2, Publisher of the University of Opole. Opole, 2010. ISSN 2082-4793. pp. 243-256.

CERTEAU, M. DE. 1984. The Practice of Everyday Life. Berkeley: University of California Press, 1984. 104 p. ISBN 0-520-23699-8.

DĘBIŃSKA, D. - KOŁSUT, B. 2011. Areas of public space in the study of conditions and directions for spatial development of selected poviat cities of the Wielkopolskie voivodeship In Practical aspects of regional research - varia vol. IV, Biuletyn Instytutu Geograf Socio-Ekonomiczna i Gospodarki Przestrzennej UAM, Series Development Regional and Regional Policy, No. 16, 2011. Poznań. ISBN 9788362662876. pp. 99-106.

FRANTA, A. 2004. Space direction. On improving the public space of the city. Cracow: Cracow University of Technology Tadeusz Kościuszko, 2004. ISBN 0860-097X.

FRYSZTACKI, K. 2005. Between space and urban audience. In Changes of the city. Around the sociology of Alexander Wallis. Warsaw: Scholar Scientific Publisher, 2005. ISBN 83-7383-132-0, pp. 151-158.

GĄDEK, A. 2006. Revitalization as a method of building a new image of the city on the example of Nowa Huta. Master's thesis written under the direction of Rudnicki Z. Kraków: Cracow University of Economics, typescript. 2006. 58 p.

GRYCZYŃSKI, A. 2007. Nowa Huta - the youngest sister of Krakow. Krakow:

Nowohuckie Centrum Kultury., 2006. ISBN 9788388832512, p. 4.

HANSEN, T. B. - VERKAAIK, O. 2009. Introduction urban charisma: On everyday mythologies in the city. In Critique of Anthropology. ISSN 14603721, 2009, vol. 29, no. 1, p. 9.

HŁADKIEWICZ, W. 2006. The concept of public space in the theory of Jurgen Habermas In Public sphere. Condition-manifestations-transformation. Lublin: UMCS publishing house, 2006. ISBN 83-227-2530-2.

JAŁOWIECKI, B. - SZCZEPAŃSKI, M. S. 2002. City and space in the sociological perspective. Warsaw: Scholar Publishing House, 2002. ISBN 837383-197-5, pp. 379-425.

KARWIŃSKA, A. 2008. Spatial economy. Socio-cultural conditions. Warsaw: Wydawnictwo Naukowe PWN, 2008. ISBN 978-83-011-5445-5.

KOCHANOWSKA, D. 2009. Public space: two questions. In Contemporary Shaping of Public Space. p. 19.

KOTKIN, J. 2007. The Rise of Family Friendly Cities. Wall Street Journal, 27 listopada. 2007. p. 2. 
KOWALCZYK, A. 2009. The process of transforming cultural resources into tourist attractions (on the example of half-battle tourism development). In Culture and tourism - collectively gained!. Łódź: Wyd. WSTH, 2009. ISBN 978-83-918688-8-1, pp. 33-46.

LIBURA, H. 1990. Perception of urban space. Warsaw: Institute of General Geology, University of Warsaw, 1990. ISBN 83-900056-5-4, pp. 91-107.

LISZEWSKI, S. 2001. The space of a post-socialist city. Research program In: Man and space, Institute of Geography and Spatial Management of the Jagiellonian University, Kraków. 2001.

LORENS, P. 2007. Thematization of public space as an expression of the diversification of the urban structure of the city of the day of globalization In Perception of contemporary urban space. Warsaw: Faculty of Geography and Regional Studies of the University of Warsaw, 2007.

MAIK, W. 2011. Public space in the city: concept, research approaches, functions and evolution of the phenomenon, In Public space of cities, XXIV Seminar of Knowledge about the City. Lódź: Publishing House of the University of Lodz, 2011. ISBN-13 978-83-7525-650-5, pp. 9-14.

MARKOWSKI, T. 2007. Public space in the process of metropolisation. In Urbanist. vol. 51, no. 7, pp. 10-15.

RIGGO, E. 2002. Child Friendly Cities: Good Governance In the Best Interests of the Child. In Environment \& Urbanization. ISSN 2547-8516, 2002, vol. 14, no. 2, p. 46.

SŁODCZYK, J. 2001. The city space and its transformations. Opole: Opole University, 2001. 310 p. ISBN 83-88796-26-7.

WĘCŁAWOWICZ, G. 2003. Social geography of cities. Warsaw: PWN, 2003. ISBN 978-83-01-15147-8.

\section{Mgr. Monika Borgiasz-Stepaniuk}

Institute of Geography

Pedagogical University, Cracow

ul. Podchorążych 2, Cracow, Poland

E-mail:m.borgiasz@gmail.com 